\title{
Treatment of ocular surface squamous neoplasia: Case report
}

\section{Liječenje skvamozne neoplazije površine oka: prikaz slučaja}

\author{
Maja Merlak ${ }^{1}$, Marijana Bilen Babić ${ }^{*}$, Andrea Dekanić ${ }^{2}$
}

${ }^{1}$ Department of Ophthalmology, Clinical Hospital Center Rijeka, Rijeka

${ }^{2}$ Department of Pathology and Pathological Anatomy, Clinical Hospital Center Rijeka, Rijeka

\begin{abstract}
Aim: Ocular surface squamous neoplasia (OSSN) is a term that encompasses a wide and varied spectrum of very rare dysplastic disease of cornea and conjunctiva, ranging from conjunctival intraepithelial neoplasia (CIN), carcinoma in situ (CIS) to invasive squamous cell carcinoma (SCC) of conjunctiva and/or cornea. Case report: In our case report, we present squamous cell carcinoma of the conjunctiva and cornea in a 78-year old man. Our diagnostic algorithm included: slit lamp and fundus examination, gonioscopy, impression cytology (IC) andmagnetic resonance imaging (MRI). The patient underwentsurgical excisional biopsy of the lesion and intraoperativecryotherapy of the cut conjunctival edges and sclera-conjuctiva base region. Following surgical therapy, we started topical $0.02 \%(0.2 \mathrm{mg} / \mathrm{ml})$ Mitomycin C (MMC) application daily for 14 days. Control excisional biopsy of conjunctival edge and abrasion of involved cornea were performed following the last day of topical chemotherapy. Our controlexcisional biopsyrevealed tumor positive corneal tissue and the second cycle of topical $0.04 \%(0.4 \mathrm{mg} / \mathrm{ml})$ MMCchemotherapy wasstarted for next 3 weeks. The patient has been followed-up for 20 months through monthly-based visits, with no recurrence of the disease. Conclusions: OSSN is a surgical challenge requiring a specialized 'no-touch' (NT) technique. In our case, the combination of surgical excision with intraoperative cryotherapy and topical chemotherapy with $0.02 \% \mathrm{MMC}$ application for 14 days, completed with second cycle of topical $0.04 \% \mathrm{MMC}$ drops for the next 21 days given the positive control biopsy, proved to be a good choice for eradication of OSSN with accurate further monitoring of the patient.
\end{abstract}

Key words: conjunctiva; cornea; eye neoplasms; mitomycin; squamous cell neoplasms

Sažetak. Cilj: Skvamozna neoplazija površine oka (OSSN) vrlo je rijetka displastična bolest rožnice i spojnice oka, sa slikom u rasponu od konjunktivalne intraepitelne neoplazije (CIN), karcinoma in situ (CIS) do invazivnog skvamocelularnog konjunktive i/ili rožnice (SCC). Prikaz slučaja: Opisali smo slučaj invazivnog skvamocelularnog karcinoma konjunktive i rožnice kod 78-godišnjeg pacijenta. Dijagnostički plan uključio je kompletan oftalmološki pregled, gonioskopiju, impresijsku citologiju i magnetsku rezonanciju (MR), te je potvrđena dijagnoza karcinoma pločastih stanica bez širenja u orbitu i ostala intraokularna tkiva. Pacijent je podvrgnut kirurškoj ekscizijskoj biopsiji lezije, uz krioterapiju konjunktivalnih rubova i skleralne baze lezije. Nakon kirurške terapije, proveli smo topičku terapiju 0,02 \% (0,2 mg/ml) Mitomycinom C (MMC) tijekom 14 dana. Kontrolna ekscizijska biopsija ruba spojnice $\mathrm{i}$ strugotine zahvaćene rožnice provedena je posljednjeg dana topičke kemoterapije. Zbog pozitivnog nalaza tumorskih stanica u rožničnom tkivu nastavljena je topička kemoterapija $0,04 \%(0,4 \mathrm{mg} / \mathrm{ml})$ MMC-om tijekom sljedeća 3 tjedna. Pacijent je redovito praćen tijekom posljednjih 20 mjeseci bez recidiva bolesti. Zaključci: OSSN je kirurški izazov jer zahtijeva specijaliziranu no-touch operativnu tehniku. U našem slučaju, kombinacija kirurškog zahvata $s$ intraoperativnom krioterapijom, te nakon toga topička kemoterapija 0,02\% kapima Mitomycin tijekom 14 dana, uz nastavljen drugi ciklus topičke kemoterapije 0,04\% kapima Mitomycin tijekom sljedećeg razdoblja od 21 dana zbog pozitivne kontrolne biopsije dobar je izbor za liječenje OSSN-a uz pažljivo daljnje praćenje pacijenta.

Ključne riječi: konjunktiva; mitomycin; neoplazme oka; rožnica; skvamocelularne neoplazme 


\section{INTRODUCTION}

Ocular surface squamous neoplasia (OSSN) is a term that encompasses a wideand varied spectrum of very rare dysplastic diseases of the cornea and conjunctiva with a figure ranging from conjunctival intraepithelial neoplasia (CIN), carcinoma in situ (CIS) to invasive squamous cell carcinoma(SCC) of conjunctiva and/or cornea.In 1995, Lee and Hirst first proposed the term OSSN and definedit as intraepithelial and invasive squamous cell carcinoma of the conjunctiva and cornea $^{1}$. The incidence of OSSN ranges from $0,02-3,5$ per 100,000 and it is well recognized that the prevalence of OSSN is increased near the equator $a^{2} a^{2}$. Risk factors include advanced age ${ }^{2}$, light skin pigmentation ${ }^{3}$, UVB light exposure ${ }^{4}$, tobacco smoke $^{5}$, exposure to petroleum products ${ }^{3,4}, \mathrm{HPV}$ infection with types 16 and $18^{6}$. Infection with human immunodeficiency virus(HIV) has been associated with higher incidence of OSSN (4-7,8\%)

OSSN isusually a slowly growing tumor and rarely spreads to corneal stroma, sclera, deeper intraocular or orbital structures ${ }^{2}$. It rarelymetastasizes to the preauricular, submandibular and upper deep cervical lymphnodes ${ }^{2}$, but systemic metastases are rare.Intraocular invasion has been reported in $2 \%-15 \%^{8}$ and orbital invasion in $12-16 \%$. In rare cases, it may lead to systemic spread disorders.

Generally, OSSN is presented asa chronic irritation, agelatinous opalescent papillary mass appearing at limbus, in interpalpebral fissure area, with feeder vessels supplying the massesand it can mimic degenerative alterations as pterygium, pinguecula or papilloma.

Clinically, the lesions are difficult to differentiate since OSSN includes benign ocular surface changes such as squamous papillomas, precancer as actinic keratosis and conjunctival intraepithelial neoplasia (CIN), carcinoma-in-situ (CIS) and squamous cell carcinoma $(\mathrm{SCC})^{2}$. In histopathological terms, conjunctival intraepithelial neoplasia (CIN) is characterized by a replacement of the conjunctival epithelium with atypical squamous cells. In carcinoma-in-situ (CIS) there is a full thickness replacement of epithelium by malignant cells, but with no invasion revealed tothe substantia propria, as opposite to invasive squamous cell carcinoma (SCC) wheremalignant cells invade thesubstantia propria.

Diagnostic procedure of OSSN includesbiomicroscopy, gonioscopy (for the assessment of intraocular angle involvement), ultrasound biomicroscopy (for the assessment of scleral and intraocular involvement), impression cytology (IC) and tissue histology, computerised tomography (CT) scans and magnetic resonance (MR) scans to to determine intraocular, intraorbital or intracranial expansion.

Ocular surface squamous neoplasia (OSSN) is a term that encompasses a wide and varied spectrum of very rare dysplastic diseases of the cornea and conjunctiva with a picture ranging from conjunctival intraepithelial neoplasia (CIN), carcinoma in situ (CIS) to invasive squamous cell carcinoma (SCC) of conjunctiva and/or cornea.

The goals in managing ocular surface squamous neoplasia are to excise the tumor with clear tissue margins and to remove any remaining tumor cells involved. The established method of treatment for OSSN is complete surgical excisional biopsy with resection of a 3-4 mm tumor-free conjunctival tissue margin and thin scleral flap below the tumor.

Affected cornea is treated with application of $100 \%$ alcohol and removal of involved epithelium to $2 \mathrm{~mm}$ from the edges of the tumor and deep down to Bowman membrane. Supplemental cryotherapy to cut conjunctival edges and scleral base is applied. Shields popularized the 'no-touch' technique while keeping operative 'dry field' without washing with Balanced Salt Solution (BSS), to prevent the dispersion of malignant cells ${ }^{10}$.

Topical chemotherapy can be used as adjunctive therapy to surgery or primary therapy. It includes Mitomycin C (MMC) as the most common application, 5-fluorouracil (5-FU) and interferon alpha $-2 b$, as less toxic compared to the previous one. Brachytherapy or internal radiation therapy are rarely used in cases of extensive or neglected lesions with unclear borders or as a palliativetherapy $^{11}$. 


\section{CASE REPORT}

In March 2013, a 78-year old man presented at our ophthalmologic emergency ward with symptoms including redness, tearing and itching of the left eye persisting for last 8 months, with a gradual decline of vision and visible swelling on his eye surface. His ocular and medical histories were unremarkable.

Ocular surface squamous neoplasia is a surgical challenge requiring a specialized 'no-touch'(NT) technique of surgery It is important that the surgeon use a minimal manipulation technique for tumor resection to avoid the transfer and implantation of tumor cells into previously uninvolved areas.

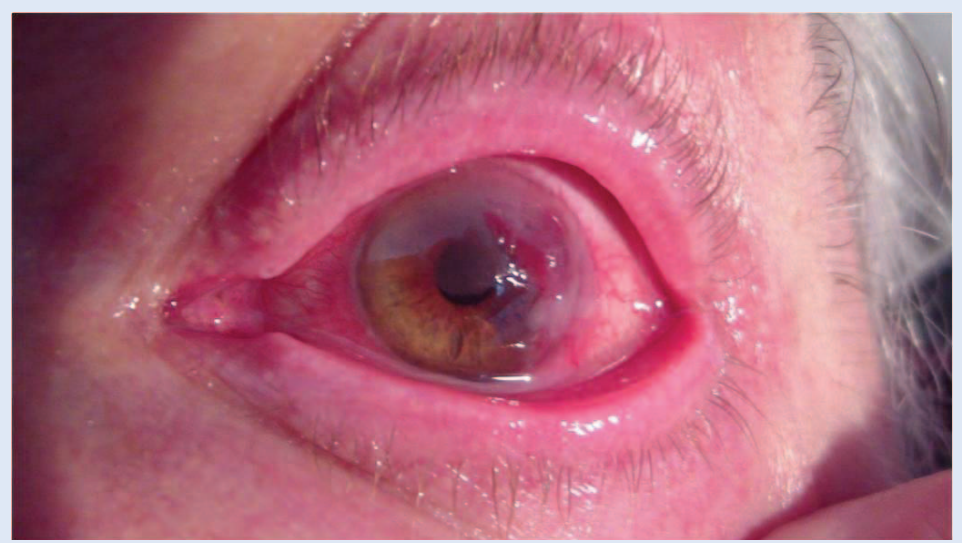

Figure 1 Clinical appearance of patient with squamous cell carcinoma of cornea and conjunctiva

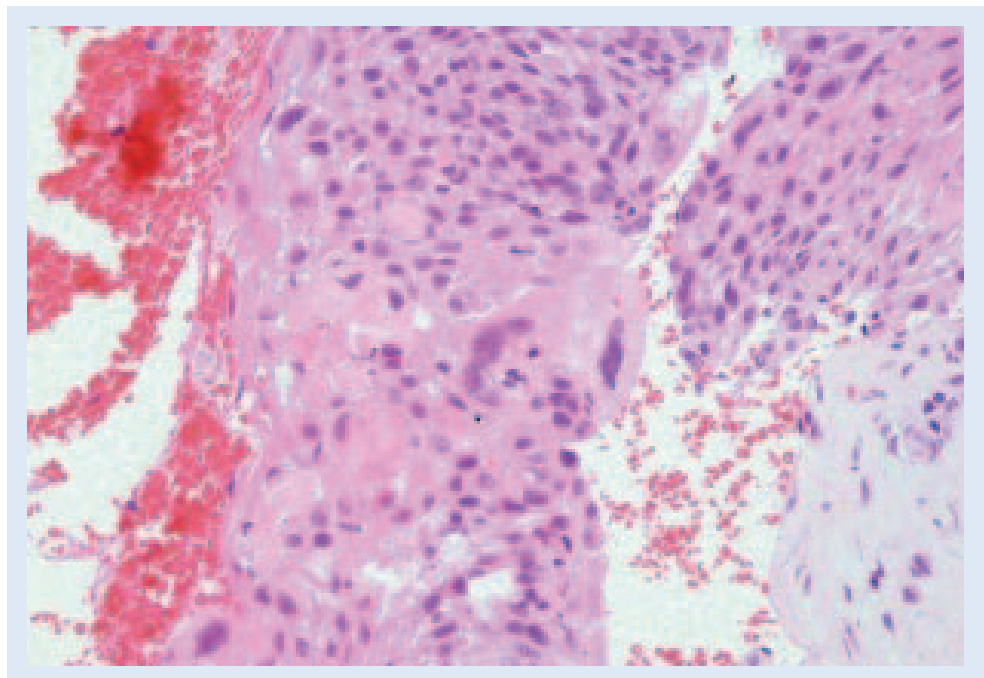

Figure $\mathbf{2}$ Immunohistochemical stains exibiting squamous cell carcinoma (Hematoxylin and eosin stain)
Patient's uncorrected visual acuity was 0.4 according to Snellen chart. Slit lamp examination showed diffuse elevated conjuctival papilloma lesion with expansion to the limbus and adjacent corneal epithelium with residential feeder vessel supplying the masses (Figure 1). Gonioscopy was performed to assess the degree of angle involvement and it showed unaffected angle in II visible part circumference of IV. Impression cytology (IC) demonstrated the presence of lesion-related malignant cells of squamous epithelium (Figure 2). Photodocumentation of ocular surface alterations were presented. Magnetic resonance imaging (MRI) scans with Gadolinium enhancement using $2 \mathrm{~mm}$ cuts showed noorbital or deeper intraocular tissue spreads. Clinical examination of preauricular, submandibular and upper deep cervical lymph nodes excluded the occurrence of invasion. Patient was also presented to the oncologist.

Our therapeutic management consisted of surgical excisional biopsy of conjunctival lesion with resection of 3-4 mm tumor-free conjunctival tissue margin and cryotherapy of cut conjunctival edge and base of the lesion. The cornealnvolved was removed with application of $100 \%$ absolute alcohol. On the first postoperative day, topical chemotherapy started with $0.2 \mathrm{mg} / \mathrm{ml}(0.02 \%)$ of Mitomycin C (MMC) with daily 2 minutes' applications for next 14 days. Control excisional biopsy of conjunctival edge and abrasion of the affected cornea were performed following the last day of MMC topical chemotherapy application. Three days after the control excisional biopsy, amniotic membrane transplantationwas performed for ocular surface reconstruction. The control excisional conjunctival-corneal biopsy revealed tumor-cells negative conjunctival tissue and tumor - cells positive corneal tissue.

Due to the positive control excisional biopsy, we started the second cycle of topical chemotherapy with $0.4 \mathrm{mg} / \mathrm{ml}(0.04 \%)$ MMC drops administered 4 times daily for the next 3 weeks.

One month following the last day of therapythe slit lamp examination showed complete clinical resolution of the lesion with onlymacula on the cornea previously surgically treated (Figure 3 ). The patient has now been followed-up for 20 
months with 1-month, 4-months and 6-months' visits respectively, with no recurrence of the disease. Patient's current visual acuity is 0.4 according to Snellen chart. There were no recorded complications due to MMC application. Patient shall be carefully monitored for thefollowing period.

\section{DISCUSSION AND CONCLUSION}

Ocular surface squamous neoplasia(OSSN) is a very rare tumor which occurs in sun damaged ocular surface, usually at the limbus in elderly men ${ }^{11}$.The most common method of treatment for conjunctival neoplasms has been wide local excision with supplemental cryotherapy to the surgical margins and primary or adjuvant chemotherapy.Topical chemotherapies can be used as nonsurgical method for treating the entire conjunctival surfacein case of multicentric or ill-defined lesions, with minimal side effects and possibility of repeating the therapy cycles depending on clinical response ${ }^{11}$.

Topical Mitomycin C has been used as most common topical chemotherapeutic treatment option that delivers high drug concentrations and can help in treating diffuse, multicentric and deep lesions ${ }^{12-13}$. It can be used pre-operatively as chemoreduction agent ${ }^{14}$ or post-operatively to minimize the possibility of recurrence of disease $^{15}$. An incomplete excision with positive surgical margins has been identified as a major risk factor for recurrence.Recurrence of OSSN after surgical treatment is common with $33 \%$ of patients with negative conjunctival margins and $56 \%$ with positive margins over a 10 -year period, as published in the study with the longest follow$u^{16}$.

Ocular surface squamous neoplasia is a surgical challenge requiring a specialized 'no-touch'(NT) technique of surgery ${ }^{10}$. It is important that the surgeon use a minimal manipulation technique for tumor resection to avoid the transfer and implantation of tumor cells into previously uninvolved areas.

In our case, the combination of surgical excision with intraoperative cryotherapy and topical chemotherapy with $0.02 \% \mathrm{MMC}$ application for 14 days, completed with second cycle of topical

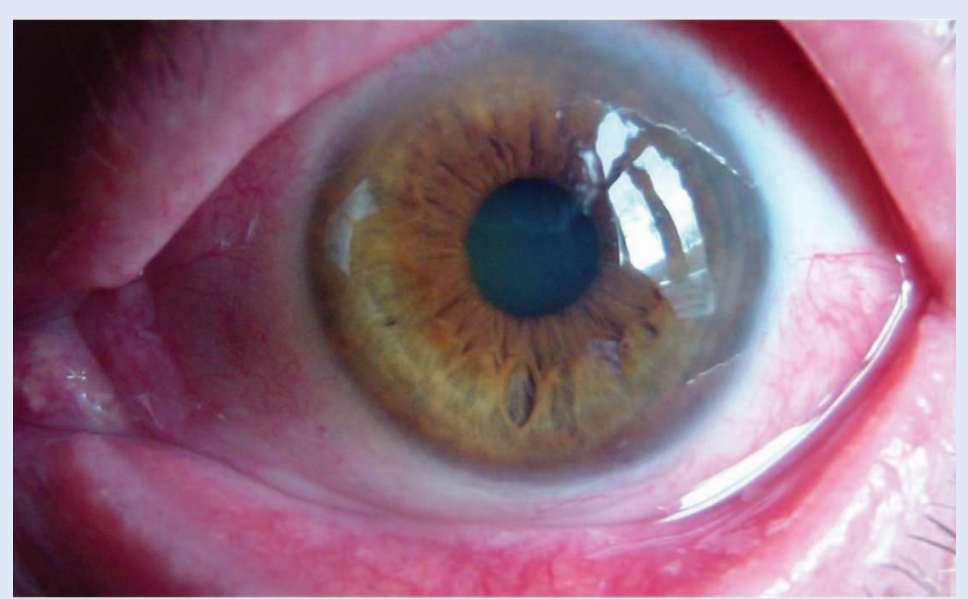

Figure 3 Clinical appearance of patient at 10-month follow up visit after treatment

$0.04 \%$ MMC drops for the next 21 days given the positive control biopsy, proved to be a good choice for eradication of OSSN with accurate further monitoring of the patient.

Conflicts of interest statement: The authors report no conflicts of interest.

\section{REFERENCES}

1. Lee GA, Hirst LW. Ocular surface squamous neoplasia. Surv Ophthalmol 1995;39:429-50.

2. Othman IS. Ocular surface tumors. Oman J Ophthalmol 2009;2:3-14.

3. Kiire CA, Dhillon B. The aetiology and associations of conjunctival intraepithelial neoplasia. Br J Ophthalmol 2006;90:109-13.

4. Lee GA, Williams G, Hirst LW, Green AC. Risk factors in the development of ocular surface epithelial dysplasia. Ophthalmology 1994;101:360-4.

5. McDonnell JM, Mayr AJ, Martin WJ. DNA of human papillomavirus type 16 in dysplastic and malignant lesions of the conjunctiva and cornea. N Engl JMed 1989;320: 1442-6.

6. Scott IU, Karp CL, Nuovo GJ. Human papillomavirus 16 and 18 expression in conjunctival intraepithelial neoplasia. Ophthalmology 2002;109:542-7.

7. Karp CL, Scott IU, Chang TS, Pflugfelder SC. Conjunctival intraepithelial neoplasia: A possible marker for human immunodeficiency virus infection? Arch Ophthalmol 1996;114:257-61.

8. Tunc M, Char DH, Crawford B, Miller T. Intraepithelial and invasive squamous cell carcinoma of the conjunctiva: Analysis of 60 cases. $\mathrm{Br} J$ Ophthalmol 1999;83: 98-103.

9. Erie JC, Campbell RJ, Liesegang TJ. Conjunctival and corneal intraepithelial and invasive neoplasia. Ophthalmology 1986;93:176-83.

10. Shields JA, Shields CL, De Potter P. Surgical management of conjunctival tumors: The 1994 Lynn B McMahan Lecture. Arch Ophthalmol 1997;115:808-15. 
11. Kim JW, Abramson DH. Topical treatment options for conjunctival neoplasms.Clin Ophthalmol 2008;2: 503-15.

12. Frucht-Pery J, Sugar J, Baum J, Sutphin JE, Pe'er J, Savir $\mathrm{H}$ et al. Mitomycin $\mathrm{C}$ treatment for conjunctival-corneal intraepithelial neoplasia: A multicenter experience. Ophthalmology 1997;104:2085-93.

13. Wilson MW, Hungerford JL, George SM, Madreperla SA. Topical mitomycin $\mathrm{C}$ for the treatment of conjunctival and corneal epithelial dysplasia and neoplasia. Am J Ophthalmol 1997;124:303-11.
14. Shields CL, Demirci H, Marr BP, Masheyekhi A, Materin $M$, Shields JA. Chemoreduction with topical mitomycin C prior to resection of extensive squamous cell carcinoma of the conjunctiva. Arch Ophthalmol 2005;123:109-13.

15. Chen C, Louis D, Dodd T, Muecke J. Mitomycin C as an adjunct in the treatment of localised ocular surface squamous neoplasia. Br J Ophthalmol 2004;88:17-8.

16. Tabin G, Levin S, Snibson G, Loughnan M, Taylor H. Late recurrences and the necessity for long-term follow-up in corneal and conjunctival intraepithelial neoplasia. Ophthalmology 1997;104:485-92. 